\title{
On the structure and variation of 'hace' as a temporal expression
}

\author{
Antonio Fábregas \\ University of Tromsø-The Arctic University of Norway \\ E-mail: antonio.fabregas@uit.no
}

\begin{abstract}
The goal of this article is to analyse a case of variation in Spanish. In most varieties, constructions of the form Hace dos días que ("it has been two days since") reject nominal expressions like todo el día ("all the day"), hence *Hace todo el día que (lit. "it has been all the day that"). However, a particular variety of Argentinean Spanish allows it. This article proposes that in the non-Argentinean varieties, hace ("make") is the spell out of a temporal relator placed in the extended projection of the verb; the nominal expression that accompanies it is a measure phrase providing the length of the vector it projects. These varieties build hace dos días que-constructions through movement of the temporal relator to the $\mathrm{CP}$ area. However, the Argentinean variety builds hace dos días que-constructions without movement, as a temporal verb that takes a durative argument. This explains the different range of nominal expressions allowed in each variety.
\end{abstract}

Keywords: temporal expressions, prepositions, viewpoint aspect, movement

\section{The problem}

The immediate goal of this article is to understand the construction that is presented in (1a), which is documented in Argentinean Spanish. The kind of nominal combined with hace, todo el día ("all the day"), is only accepted in this variety. In an apparently similar construction (1b), the same nominal expression is impossible for speakers of all varieties.

(1) a. Hace todo el día que no tengo señal. make all the day that not have.1sg signal

[Argentinean Spanish]

"I haven't had an [internet] signal for the whole day."

b. *Llegó hace todo el día.

arrived.3sg make all the day

Intended: "He arrived one whole day ago."

This temporal impersonal construction with an expression like todo el día ("all the day") is markedly ungrammatical in other varieties of Spanish, such as the European one, both in contexts like (1a) and contexts like (1b). This is surprising given the possibility of having other apparently very similar temporal expressions as a complement of hace (2); 
on the surface, todo el día and dos días (3) seem to have the same distribution as temporal expressions: both denote intervals that can be used to express duration.

(2) Hace dos días que no tengo señal.

make two days that not have.1sg signal

"I haven't had an [internet] signal for two days."

(3) a. Te he esperado todo el día.

you have.1sg waited all the day

"I have waited for you for the whole day."

b. Te he esperado dos días.

you have.1sg waited two days

"I have waited for you two days."

The questions that we will address here are as follows:

a) Why do expressions like hace dos días ("two days ago") reject a nominal like todo el día ("all the day") in all Spanish varieties?

b) Why do expressions like hace dos días que, roughly ("it has been two days since”), reject todo el día in European Spanish and most other varieties?

c) Why does the apparently same expression accept todo el día in Argentinean Spanish?

Our claim will be that temporal expressions involving ago are not temporal arguments, but temporal relators that spell out a chunk of the extended aspectual structure of the verb and express a relation between the focus time and the utterance time. The nominal expression that appears with them is a Measure Phrase modifying the length of the temporal vector they define. However, hace dos días que-constructions allow for two analyses. In most Spanish varieties, they are derived from ago-constructions through movement, but in the Argentinean variety - and in other languages - they are base generated in the first position as a temporal verb that takes two arguments. In this second case, the temporal expression is not a Measure Phrase, but a durative argument, explaining why some nominals are only allowed in the second case.

The article is structured as follows: section 2 deals with the hace dos días-construction; section 3 presents the analysis of the hace dos días que-construction in European Spanish; and section 4 presents the analysis of the same surface sequence in Argentinean Spanish.

\section{Hace dos días: analysis}

The first thing we need to do is to discuss the semantics of our construction. In order to do so, let us consider the meaning of the sentence in (4).

(4) Escribió su tesis hace tres días. wrote.3sg her thesis make three days "She wrote her thesis three days ago."

Here we have a temporal expression, hace tres días ("three days ago"). What this expression does is to relate the time of utterance - the point where the sentence is uttered, let us say 31 December 2014 - and the ending point of a particular event - the moment 
in which the dissertation is completely written. Note that the expression does not relate the point of utterance directly with the time of the event: we know this because the event of writing a dissertation occupies a non-trivial time interval. It is started at some point, it has a progression that typically spans a couple of years, and it ends at some point. From (4) we cannot deduce when the author of the dissertation started the work; we cannot know, either, how long it took her to complete the dissertation. What the expression hace tres días tells us is the temporal distance between the moment when I say this sentence and a particular time: the endpoint of the event. In Klein's (1994) terms, what the expression does is to give us the distance between the time of utterance and the focus time, which highlights a particular time interval in relation to the event time. Thus, we have three temporal levels:

(i) the event time: the timespan where the eventuality described by the verb (in our example, escribir su tesis ("to write her dissertation")) takes place. In this article, we will mark with ...++++... the temporal span not occupied by the eventuality; ...---... marks the temporal span occupied by the eventuality; we use the convention | to mark the initial point and the endpoint of the eventuality (boundaries, in the sense of Piñón 1997), without implying necessarily that the endpoint has to be a culmination point.

(5)

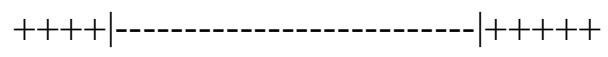

(ii) the focus time or viewpoint aspect: the temporal point or interval the statement is about, built over the event time. In our example, with a form in aorist (perfective, Smith 1991, García Fernández 2000), this involves focusing the endpoint in the eventuality. Following common practice, we will codify the focus time enclosing the relevant time interval between square brackets, [ and ].

(6)

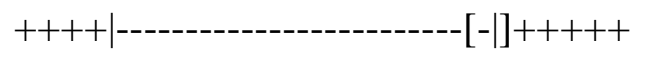

(iii) the utterance time: the point in time where the whole sentence is uttered.

Given this situation, here is how hace tres días allows the speaker to make a calculation about exactly when the dissertation was written. Hace tres días defines a vector that is projected backwards in time from the utterance time to the focus time, in our case, the endpoint of the eventuality 'writing a dissertation'.

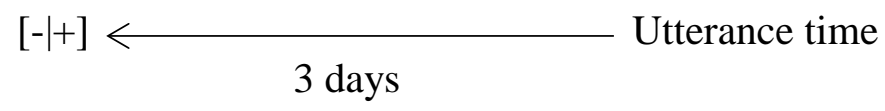

The orientation of the vector is given by the lexical semantics of hace: it is projected backwards. The length of this vector is given by the quantificational expression that accompanies hace, tres días ("three days"). With this operation, we can place the endpoint of the writing event as 28 December 2014, because our utterance time was 31 December 2014.

What is interesting at this point is that the semantics of hace tres días is not too different, mutatis mutandis, from the semantics of a place P. Just like place Ps, what this expression does is to give us the relation between two entities, and that relation is calculated 
projecting a vector that identifies the position of the first entity by reference to the second entity; the vector can have an orientation, and some particular length that can be specified:

The spider is three meters behind the tree.

As in (8), here we have an expression that relates the position (in this case, the spatial position) of two entities: the tree and the spider. This is done by projecting a vector whose orientation is given by the lexical meaning of behind, and whose extension is given by a quantificational expression, three meters. With these ingredients, the speaker is able to locate in a dimension the spider by reference to the position that, in the same dimension, the tree has. This is essentially the same situation we find with hace tres días: we locate (in time) the endpoint of the writing event by a three-day long vector that relates it to the utterance time. In what follows, we will take advantage of this parallelism to propose a structure for hace + quantifying expression constructions.

\subsection{The structure after first merge}

There are two properties ${ }^{1}$ that in principle do not match the parallelism with locative PP expressions well that we have sketched in the previous introduction.

a) This expression relates two temporo-aspectual objects (utterance time and focus time), not two (referential) entities, as PPs do.

\footnotetext{
${ }^{1}$ There is an additional prima facie difference that needs to be addressed immediately in order to avoid potential confusions. In hace tres días, intuitively it seems that we are calculating the focus time using the utterance time as a reference point. However, this is likely to be an illusion forced by what entity is more likely to have a fixed value shared by speaker and addressee in any particular interaction. What happens is that in any given (spoken) utterance, the time that can be taken as identifiable by both speaker and addressee is the time where the sentence is uttered, because both are at the same time there and its value is fixed deictically. Once a relation is established between the utterance time and the focus time, it makes sense that this value is taken as a reference to identify the position of the second. Our contention will be that with hace expressions, the structural ground is the focus time, even if its temporal position is generally unknown, and the structural figure is the utterance time, even if its temporal position is known by speaker and addressee. This is, after all, not so different from some non-cannonical cases in the spatial domain. Talmy $(1972,1983)$ noted that, when prepositions establish relations between entities, it is pragmatically preferred to interpret the bigger, more stable entity as ground (i), but this does not make it semantically impossible to use it as figure and locate the ground by reference to it (ii):
}

(i) a. The cat is behind the house.

b. The house is in front of the cat.

(ii) [Come on, don't you see my house!] It is right behind the yellow car.

In fact, our situation can be compared to the following one in the spatial domain: imagine a moving ground (thus, a ground whose position has not been agreed upon by speaker and addressee) and a static figure: the speaker can help the addressee calculate the position of the ground by giving it a vector, its orientation and its length, projected from the ground towards the fixed figure. See the following example, that a radar technician can use to describe the position of the rocket:

(iii) [What do you mean you cannot find the rocket?] Spain is now 20 kilometers to the left of the rocket.

All in all, our claim is that which entity is, conceptually, used as a reference point and which one is located is a poor test for groundness, as different pragmatic and world-knowledge considerations can come into play and make it more plausibly that the entity with the fixed position is the figure. 
b) This expression has the morphophonology of a verb, not a preposition. In fact, the expression can carry temporal morphology (García Fernández 2000: 155), although this temporal marking is uninterpretable and analysable as agreement with the main verb's temporal domain (Bosque and Gallego 2011) with only one exception, to which we will come back:

a. Dijo que había venido hacía unos días. said.3sg that had.3sg come made.impf some days

"He said that she had arrived some days ago."

b. Cuando lleguen sus padres, Juan habrá terminado la tesis hará. un mes when arrive.subj his parents, $\mathrm{J}$ will.have finished the thesis make.fut one month "When his parents arrive, Juan will have finished the dissertation already one month ago.”

As usual, an analysis where these two properties follow from the same core would be appealing. Here is our proposed structure: hace is structurally a constituent in the extended projection of the verb's aspectual domain. It acts as a relator between two temporal intervals, the utterance time and the focus time. Like these, the two surprising properties of this expression are tied together: it has a verbal morphophonology because, indeed, it is a relator that is placed in the aspectual domain of the clause, taking an extended verbal phrase as its complement.

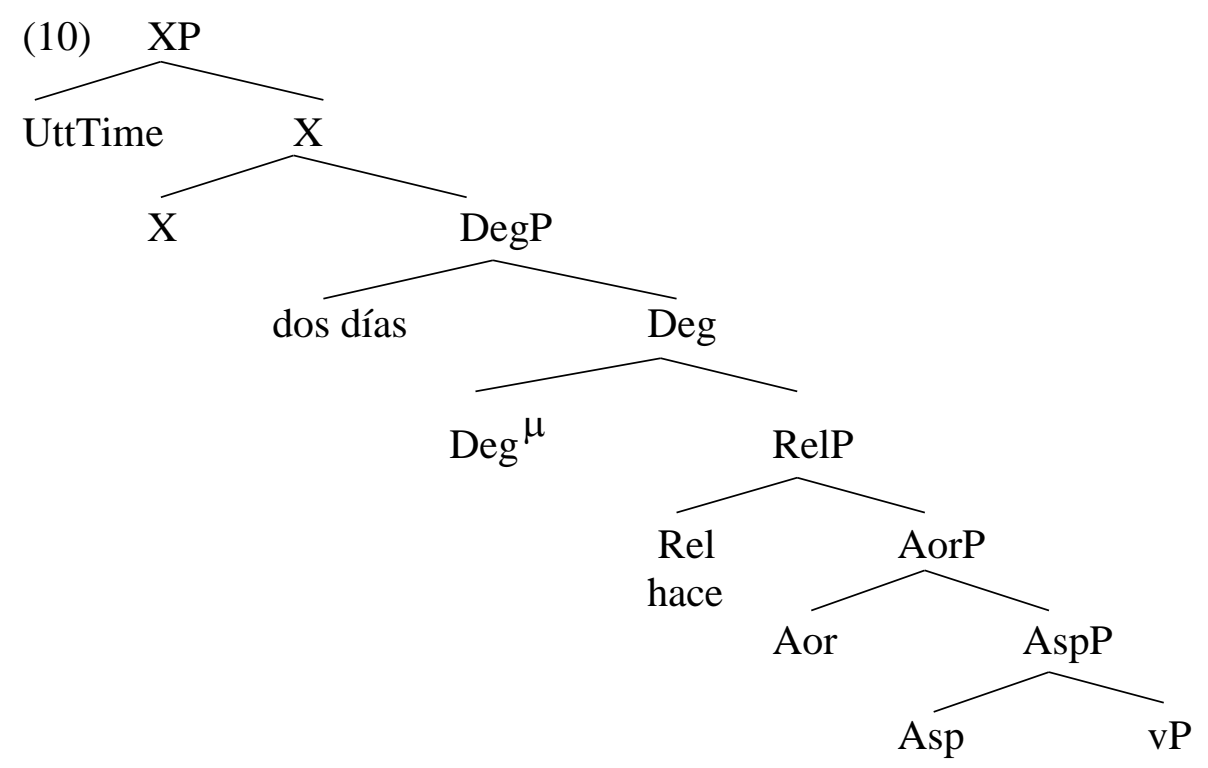

For expository convenience, we mark hace as the spell out of a Rel head, even though later it will become clear that it is the synthetic spell out of three heads: Rel, Deg(ree) and X. Hace is a preposition-like relational head (we borrow Rel from Romeu 2013) that connects two temporal intervals: the focus time, here represented as Aor(ist)P, and the utterance time, here UttTime. The focus time is itself a complex constituent, that contains the event time $(v \mathrm{P})$ and builds over it a situation (AspP) that takes a particular value (AoristP), thus defining a relevant interval. See section 2.4 for the technical details of how this sequence is created even though, in principle, $v$ and $\mathrm{T}$ are separated by the relational structure corresponding to hace.

Starting from this interval, RelP, here with a value 'backwards', projects a vector. This vector has some precise length, which is measured by Deg, with a bounded value (cf. Svenonius 2010), The nominal phrase that accompanies the hace expression is the 
specifier of this degree phrase, equivalent to the measure phrase in expressions like (11) (cf. also Brugè and Suñer 2009):

(11) dos metros más alto two meters more tall "two meters taller"

This explains, correctly, that as noted by Sáez del Álamo (1987: 720) the nominal expression cannot be pronominalised:

(12) hace dos días --> * los hace

make two days --> them make

"two days ago"

In our structure, the head and the measure phrase are not in a head-complement relation, and therefore they do not count as a pronominalisable argument. In fact, it is unclear whether measure phrases are arguments at all, but even if they were, they would not be internal arguments of the relevant heads.

It might be helpful to compare (10) with (13), a standard case of prepositional expression relating two entities, adapted from Svenonius (2008):

(13) the cat (is) two meters in front of the house

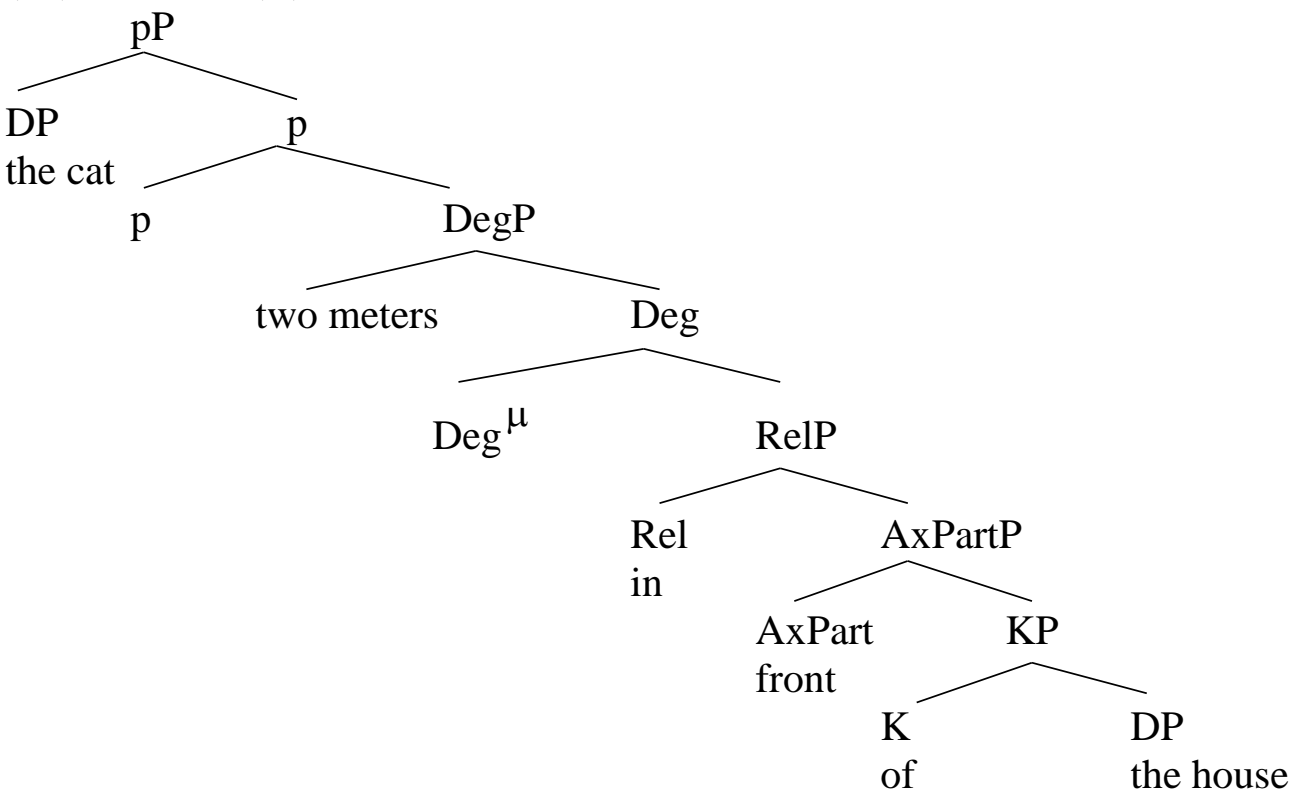

Here we start from a referential expression (the house). This expression is mapped into a region - defined as a sets of adjacent points (Wunderlich 1991; Zwarts and Winter 2000) - by KP. Axial Part (AxPart) selects part of the points in the region: in our case, from all the space that is defined by the house, only its front will be relevant. The preposition itself (Rel in our notation) projects a spatial vector from the area defined by AxPart; it defines the orientation of that vector by its lexical meaning: behind would project it in a direction, above in another one, etc. Deg can give the length of that vector, expressed through a quantifier phrase. There is an additional functional head, $p \mathrm{P}$, which is responsible for allowing the preposition to combine with a second argument, the figure. 
The parallelism with our structure could be worth exploring. In our structure, we start with an event $(v \mathrm{P})$. AspectP is the projection whose role is to map an event into a situation (cf. Ramchand and Svenonius 2013), which we can define as a set of adjacent temporal points. Above AspectP, which turns the event into a temporo-aspectual object, there are different aspectual values that select different areas inside the set of points defined by Asp - in other words, the different external aspectual values would be the different manifestations of AxParts in the verbal domain. Taking this temporal AxPart as a complement, hace comes in and projects a vector with a length determined by the measure phrase contained in DegP; this vector connects the situation time with the utterance time.

Of course, a mere parallelism cannot be taken as evidence in favour of a proposal, but it certainly cannot hurt that the pieces required to build a spatial relation in the nominal domain can be matched with the pieces that we are proposing to analyse a temporal relation in the verbal domain. In what follows, we present independent evidence for each one of these steps.

\subsection{Preliminary evidence}

We take it for granted that the ordering [AspP [ $v \mathrm{P}]]$ does not need to be motivated: it is the standard representation of the dialogue between Aktionsart - at the $v \mathrm{P}$ level - and External Aspect - defined as AspP - see Bertinetto (2000) for evidence that requires these two levels to be distinct, Zucchi (1993) for evidence that these two levels represent different semantic objects and Ramchand and Svenonius (2013) for evidence that AspP in fact acts as a transitioner between events and situations.

The first claim that needs to be motivated is treating aorist aspect (or the imperfective, perfect, prospective, etc. aspects) as two separate heads instead of treating them as different flavours of the same head. That is, as opposed to an option like (14), with different aspectual heads, we are proposing (15), with aspect being always the same head and its different values being defined by additional heads merged above them:

(14) a. $\left[\operatorname{Asp}^{0}<\right.$ aorist $\left.>\right]$

b. $\left[\operatorname{Asp}^{0}<\right.$ imperfective $\left.>\right]$

c. $\left[\operatorname{Asp}^{0}<\right.$ perfect $>$ ]

d. $\left[\right.$ Asp $^{0}<$ prospective $>$ ]

(15) a. [AoristP [AspectP]]

b. [ImperfectiveP [AspectP]]

c. [PerfectP [AspectP]]

d. [ProspectiveP [AspectP]]

The choice between (14) and (15) largely depends on the nature one assigns to features in one's theory; (14) treats features as properties of heads, while (15) treats features as independent entities that cluster together to form different 'molecules'. This is a change of perspective that took place in phonology in the 70s, with Chomsky and Halle (1968) presenting a traditional feature-as-property account and subsequent autosegmental proposals (Goldsmith 1976) analysing features as objects independent of the segments they define. Our choice of (15) is largely consistent with this second view, now preponderant in phonology, and with the general nanosyntactic enterprise (Starke 2009). 
One direct piece of evidence would be to find cases where each of the two heads involved in (15) are spelled out by separate morphophonological objects. We believe that such cases exist. Consider the following well-known pattern of data from Spanish:
a. acaba de come-r
finish of eat-inf
"he has just eaten"
b. va a come-r
goes to eat-inf
"he is going to eat"
c. termina de come-r
end of eat-inf
"he finished eating"

What we have here is three different aspectual values codified by three different periphrases, all of them taking an infinitive as its complement. There are three components: the infinitive, a preposition whose status is unclear and an auxiliary verb. Interestingly, the first construction expresses perfect aspect - the state immediately following the endpoint of the eating event. The second expresses prospective aspect (Bravo 2008) - the preparatory state immediately preceding the starting point of the eating event - and the third expresses aorist viewpoint aspect - the endpoint of the eating event. The marker of these three values cannot be the infinitive, because the same form is used in all three cases, and it is not likely to be the preposition either, because in two out of the three cases it is the same form, de ("of"). However, the three elements are equally necessary. This suggests that in order to define a specific aspectual value through the auxiliary - more structure needs to be built below it, through a preposition and a particular non-finite form of the verb: this would be our AspP, which is likely to correspond in our examples to the preposition that intervenes between the non-finite verbal form and the auxiliary. Similarly, Svenonius' (2008) KP in the nominal domain is also manifested as a semantically impoverished preposition (17), and its function is also to act as a transitioner between one domain (entities) and another (regions).

\section{in front of the house}

Consider now evidence that hace takes the aspectual value as its complement. It has been noted that not all external aspect + hace combinations are possible, something that follows from a simple case of selection if Rel selects the aspectual value as its internal argument. The first incompatibility is with prospective aspect, manifested in Spanish through the ir $a+$ infinitive construction.

(18) *Va a llegar hace dos días.

goes.3sg to arrive make two days

"*She will arrive two days ago"

This impossibility is explained with our structure, formally, but does not have a clear semantic explanation once we think about the details. In such a combination, grammar asks us to select a point in an interval that precedes an event and leads to it, and project from it a two-day long backwards vector. We see no semantic reasons to make this impossible: we would be placing in time, two days in the past from our perspective, the interval where the preparations for his arrival where happening. The clash, then, cannot be explained as a 
conceptual effect. However, in our structure it can be codified as a case of selection: imagine that hace, given that it projects backward vectors, selects for aspectual values whose viewpoint follows the starting point of the event: imperfective (between the starting point and the endpoint), aorist (the endpoint) or perfect (after the endpoint).

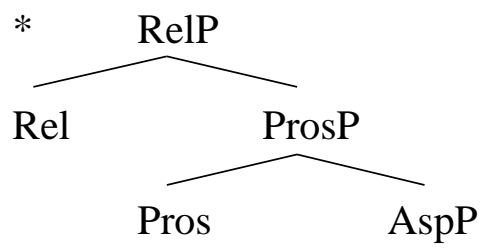

The incompatibility with achievements in the present can also be treated in the same way (20):

(20) *Llega hace dos horas. arrive.3sg make two hours "He arrives two hours ago"

As noted by Piñón (1997), achievements denote mere boundaries without internal development; this forces a quasi-prospective interpretation in the present tense; when we say (21), we say that we are in the preparatory state that immediately precedes the Three Wise Men's arrival:

(21) Ya vienen los Reyes Magos

already come the Kings Magicians

"The Three Wise Men are coming"

Other contrasts also show that hace selects the viewpoint aspect and picks one temporal point inside it. Take stative verbs:

(22) a. *Juan odia a su madre hace dos años. Juan hates.pres ACC his mother makes two years

Intended: "Juan hates his mother since two years ago."

b. Juan odia a su madre desde hace dos años. Juan hates ACC his mother since makes two years "Juan hates his mother since two years ago."

The contrast presented here shows that with stative verbs in the present, hace is unable to combine directly with the temporo-aspectual structure. Instead (22b), a path preposition (desde, "since") has to be used. The explanation follows from our explanation: assuming that present is imperfective, the problem with stative verbs is that they do not have salient temporal points that can be picked as the origin of the vector. States are non-dynamic, and they do not by themselves define endpoints; in the case of a stative like odiar ("hate"), moreover, the verb is an Individual Level predicate (Milsark 1974, Carlson 1977), which means that the property would be strongly implied to be persistent (McNally 1994). This means that (a) the properties denoted by the verb would hold of the subject across a long timespan; and (b) the viewpoint aspect used (imperfective) would not define any endpoint or salient boundary inside the time of the eventuality, making it impossible to find a point to anchor the vector. Adding a path preposition solves the issue in the sense that path prepositions do not select points, but contiguous series of points (Zwarts 2005), something that avoids having to select one single specific point in the time of the 
eventuality, because then a whole temporal path (covering the whole eventuality, from an arbitrary starting point to the moment of utterance) can be picked by the temporal expression. We will go back to the nature of temporal paths in section 2.5.

Using past tense forms solves the issue:
(23) Juan odiaba
a su madre hace dos años.
Juan hated.past.impf ACC his mother makes two years
"Juan hated his mother two years ago."

The reason is that now the use of the past tense activates the implicature that there has been an endpoint to the eventuality; this defines a salient point inside the temporal structure of the situation that can be taken as the origin of the vector, and the relation with the utterance time is calculated from there.

Consider now the evidence that the nominal expression combining with hace is indeed a measure phrase. Notice that expressions that can otherwise be taken as temporal grounds cannot combine with hace.
a. Llegó después de la cena. arrived.3sg after of the dinner "He arrived after the dinner."
b. *Llegó hace la cena. arrived.3sg make the dinner Intended: "He arrived the dinner ago."

The expressions that can combine with hace are restricted to indefinite QPs: imagine that we have periodic dinners (one every month) for the professors of the department, and we want to note that in the last two dinners Juan has not participated. Then (25a) is fine.
a. Vino hace dos cenas. arrived.3sg make two dinners "He arrived two dinners ago."
b. Vino hace dos días. arrived.3sg make two days "He arrived two days ago."

This restriction to the nominal expressions - indefinite QPs - matches the restriction that other measure phrases have to follow in other domains: consider first verbs of physical measurement (26), and then measure phrases used as specifiers of comparative adjectives (27).
a. Pesa dos kilos. weighs.3sg two kilos "He weighs two kilos."
b. *Pesa el kilo. weighs.3sg the kilo
c. *Pesa los dos kilos. weighs.3sg the two kilos


(27) a. dos metros más alto two meters more tall "two meters taller"

b. *los metros más alto the meters more tall

c. *los dos metros más alto the two meters more tall

Note that if we treat the nominal expression accompanying hace as a measure phrase, we can also explain why todo el día ("all the day") is expected to be excluded if the structure is right: definite holistic QPs cannot be used as measure phrases.

(28) a. *Pesa todos los kilos. weighs.3sg all the kilos

b. *Mide todos los metros. measures.3sg all the meters

c. *todos los kilos más gordo all the kilos more fat

\subsection{The structure of hace dos días}

Let us now zoom in and concentrate on the portion of the structure that represents the structure of hace dos días, excluding its ground (the focus time) and its figure (the utterance time).

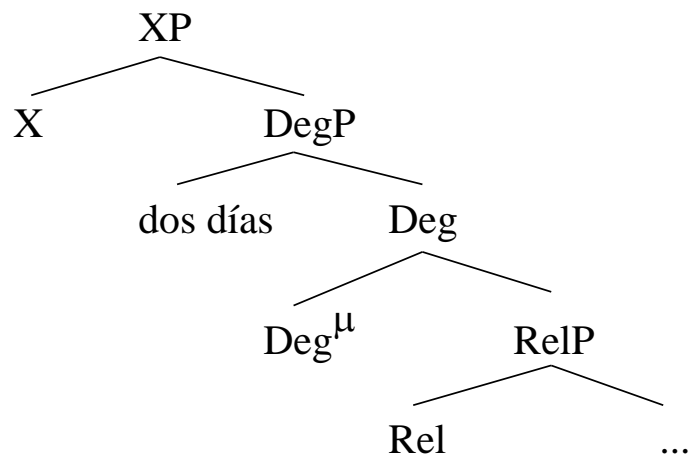

If we take a look at how this kind of expressions are spelled out across languages, we do not need to travel very far to see that there are three logical options, predicted by this structure, where there are three heads involved.

a) Option A: one single preposition, linearised to the left of the measure phrase (Spanish)

(30) hace dos días

make two days

"two days ago"

b) Option B: two prepositions, one to the left and one to the right of the measure phrase (Norwegian bokmål) 
(31) for to dager siden

for two days since

"two days ago"

c) Option C: one single preposition, linearised to the right of the measure phrase (English)

(32) two days ago

\subsubsection{One form to the left}

Starting with Spanish, our contention is that hace in this context is the spell out of the series of heads X, Deg and Rel:

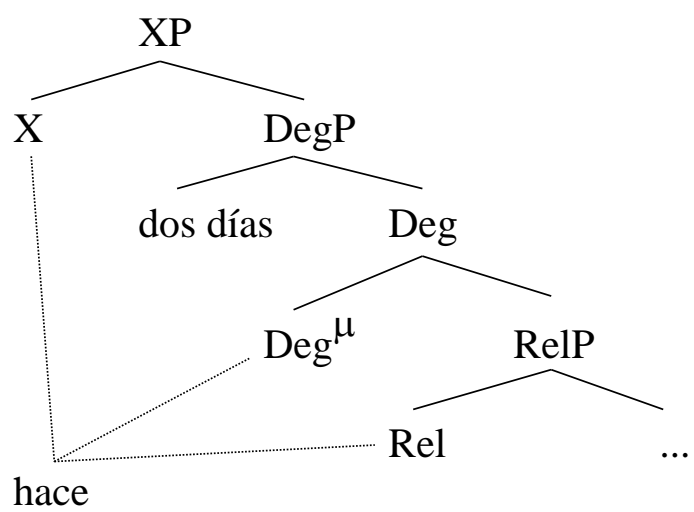

We employ the neutral label $\mathrm{X}$ for the highest projection because its exact label is still open for discussion. It can certainly be compared to the functional head $p$, proposed in Svenonius (2008) as an equivalent to $v \mathrm{P}$ in the prepositional domain - the head responsible for introducing the external argument of the preposition. We treat it as the function that provides the vector with the second member inside the relation, which in our case is the utterance time.

There are different technical ways of obtaining the result that the same exponent spells out that series of heads. The representation in (33) follows the conventions of Ramchand's (2008) spanning approach, where adjacent heads can be lexicalised by the same exponent, ignoring specifiers. Brody's (2000) Mirror Spell Out can also capture this pattern of data: hace would be the spell out of a set of features distributed across different heads, and its linearisation would be done at the hierarchical point of the highest of them, after movement to a specifier position. Svenonius (2012), whose theory combines insight from both Ramchand and Brody, would also account for this result, to the extent that he allows both complex specifiers and series of heads to lexicalise as words. Obviously, traditional head movement would work equally well in this case. Phrasal Spell Out (Caha 2009) could also be adopted, provided that we assume that the complement of Deg displaces to form one single constituent with XP in the exclusion of the measure phrase.

\subsubsection{The different forms of hace}

Be it as it may, what we are claiming is that hace corresponds to the spell out of a complex syntactic constituent that acts as a relator between temporal intervals. As such, we can 
explain two properties of hace that have been noted in the literature. One of them has already been mentioned: hace can carry tense morphology, but it is not interpretable.

(34) Había venido hacía unos días. had.3sg come made.impf some days "He had come some days ago."

This inflection is not independent from the main verb's inflection, as witnessed by the following example. Semantically, note that we could interpret it as 'at some point in the past (corresponding to my wedding), it had been two days since he finished his novel':

(35) *Escribió la novela (antes de mi boda) hacía dos días. wrote.3sg the novel (before of my wedding), made.impf two days

This suggests that one of the heads in our sequence carries uninterpretable tense-aspect features that have to be checked with the tense under certain conditions. This is the complete set of possible and impossible agreeing forms:

(36) a. *Escribió el libro hizo unos días. wrote.3sg.aor the book made.aor some days

b. *Escribía el libro hacía unos días. wrote.3sg.impf the book made.impf some days

c. Escribía el libro hace unos días. wrote.3sg.impf the book make.pres some days

d. *Ha escrito el libro ha hecho unos días. has written the book has made some days

e. *Escribirá el libro hará unos días. will.write.3sg the book will.make some days

f. Había escrito el libro hacía unos días. had.3sg written the book made.impf some days

g. *Había escrito el libro había hecho unos días. had.3sg written the book had made some days

h. Había escrito el libro hace unos días. had.3sg written the book make.pres some days

i. Habrá escrito el libro hará unos días. will.have.3sg written the book will.make some days

There are only two agreeing forms accepted by hace: imperfective past (36f) and future (36i) (although not all speakers accept this second form, pace García Fernández 2000: 155). What they have in common is that they are imperfective aspectual forms. There is only one context where this agreement is possible, when the main verb is a form with haber + participle. Compare (36b) with (36f), and (36e) with (36i); even speakers that find (36i) marked agree that (36e) is considerably worse. However, in these contexts agreement is not compulsory: (36h) is possible, without apparent meaning differences with (36f).

However, there is one form of hace that is interpretable: the future and the conditional, when used as conjecture forms: 
(37)

a. Terminó la novela hará tres meses. finished.3sg the novel will.make three months "He finished the novel, I believe that three months ago."

b. Había terminado la novela haría tres meses. had.3sg finished the novel would.make three months "He had finished the novel, I believe that three months ago."

As the reader has noted, haría is the form used for conjectures in contexts where one expects agreement between hace and the main verb.

These facts, together, ask for an enrichment of the structure of hace in Spanish. Let us start with the possibility to define modal meaning on its own. Our proposal places hace expressions in the area between aspect and tense, which we know, independently, can be occupied by modal auxiliaries, as the following contrast witness.

(38) a. Juan puede estar nadando toda la tarde.

Juan can be swimming all the afternoon

"Juan is able to / has permission to swim for the whole afternoon."

b. *Juan está pudiendo nadar toda la tarde.

Juan is being.able.to swim all the afternoon

This contrast suggests that the modal area is structurally higher than the aspectual area. Given that this area is shared by hace in our proposal, it is not surprising that the temporal relation it expresses can be embedded under a modal: we propose that this is the structure of hará in its modal use.

(39)

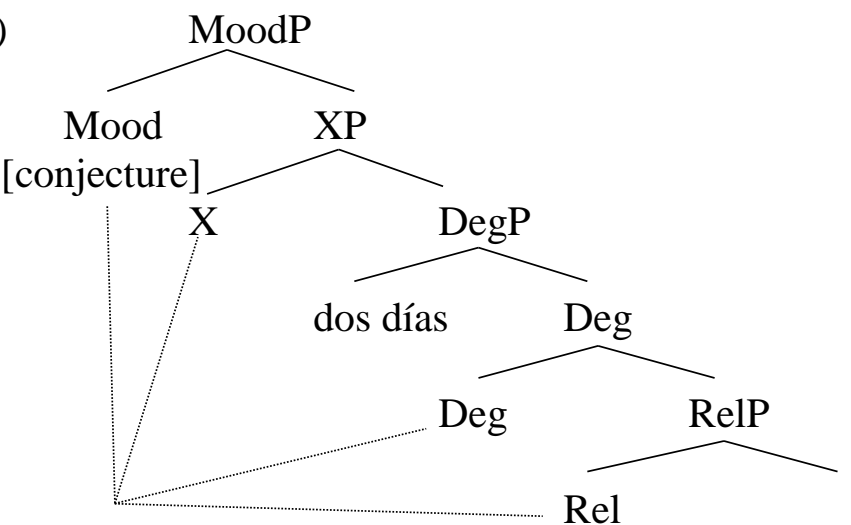

hará

However, in the cases where the temporal form of hace is uninterpretable, we propose pure agreement, which does not involve introducing a new head, but rather checking some features contained in a head. For concreteness, we will propose that these features are contained in XP; however, we will not develop the analysis fully here. ${ }^{2}$

\footnotetext{
${ }^{2}$ Obviously, the analysis of the complex pattern presented in (36) would call for an independent article. There are several factors that would have to be explored. First, the optionality of agreement could be captured in two forms: either by assuming that $\mathrm{X}$ does not always carry agreement, or by allowing agreement to be resolved through insertion of a default value for the feature (Preminger 2014). Second, an important problem is what value of Asp actually the form agrees with. It seems that the forms are restricted to imperfectives, something that could follow in two different ways: with imperfective being a default value or by defining it explicitly. In the first case, an option would be to say that agreement actually happens with
} 
(40)

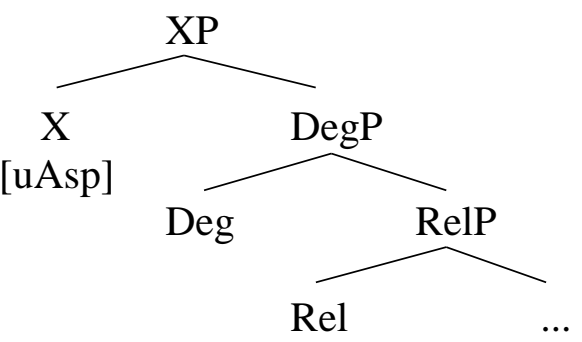

\subsubsection{One form to the right}

The situation in English can be treated as in Spanish in several respects: to begin with, as in Spanish, the form ago is originally related to a verbal form: the participle agone, from the old verb agon ("to pass, to depart"). Moreover, it is a well-known property of the standard analyses of English that its morphology is impoverished with respect to Spanish, which results in heads that are spelled out in a lower position, with possible PF-lowering of the morphology associated with the higher heads (e.g. Chomsky 1957; Marantz 1988; Halle and Marantz 1993; Bobaljik 1994).

Our structure in fact predicts that English would materialise the temporal expression to the left of the nominal, if the nominal is, indeed, a measure phrase. Again, there are different technical options for the details, that are largely orthogonal to our purposes: we can assume ø morphemes under Deg and $\mathrm{X}$ in English, or lowering of its features for purposes of spell out; we can also assume that the spell out algorithm of English stipulates that in a series of contiguous heads, the exponent is introduced in the lowest of them (explaining simultaneously the position of the verb and this case). For explicitness, we will assume an analysis where ago is generated as Rel and does not rise to Deg or X. The reason is that this will explain why it cannot further combine with modal information, unlike in Spanish: there are intervening heads that make it impossible for ago to combine with a modal exponent.

$\mathrm{T}$ (past or future), with imperfective forms being the default materialisation of past in the absence of aorist. This would force a treatment of aorist as a purely aspectual form, something that is not completely implausible. This line or reasoning could also explain why agreement is restricted to perfect forms if we assume that what hace agrees with is the past or future tense that combines with the perfect value. In any case, we leave the exploration of these options for further research. 
(41)

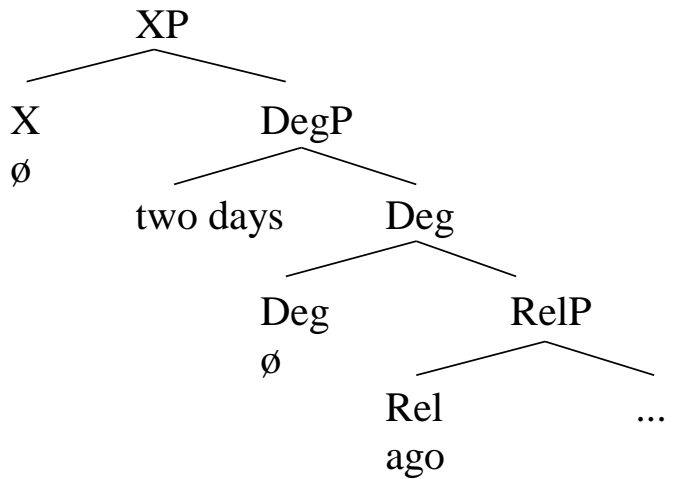

(42)

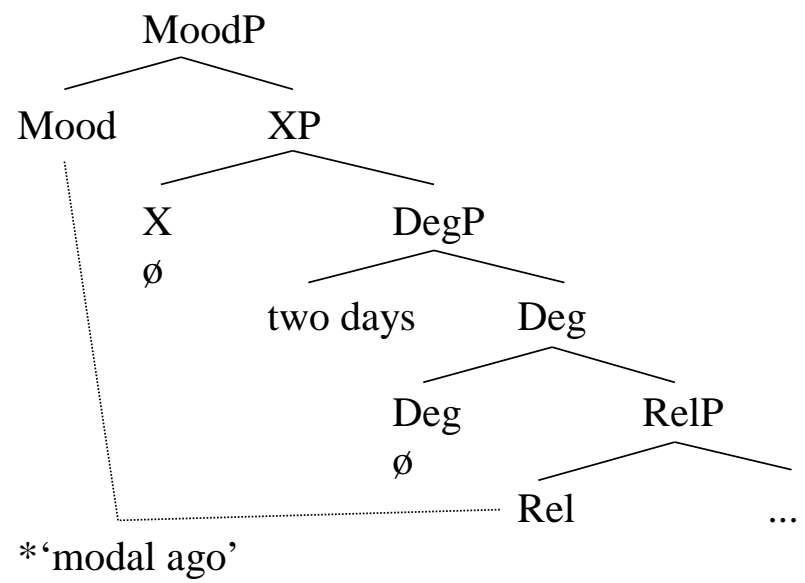

\subsubsection{Two forms}

Finally, our proposal that there are at least two heads involved in the construction of hace directly predicts a third typological option, which is that each one of them is materialised with a different exponent, with the measure phrase placed between them.

(43)

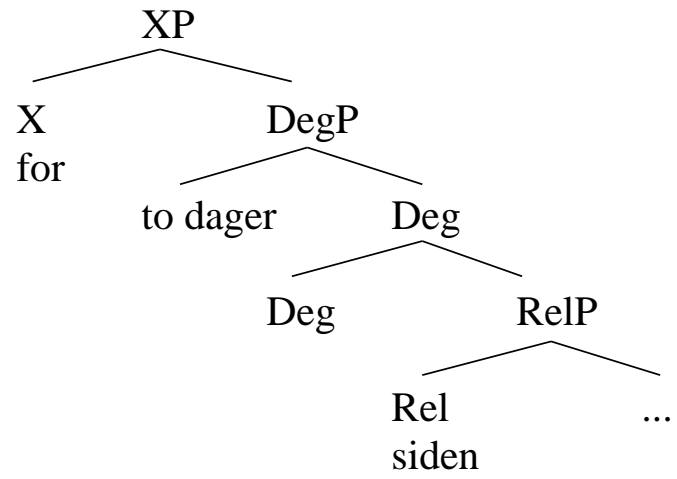

However, there are differences here: Norwegian uses two exponents that are otherwise used in the nominal domain, even if siden ("since") is specialised as a temporal preposition:

(44) a. Dette var en grusom dag for oss alle.

this was a horrible day for us all

b. Over 500 drept siden mars.

more.than 500 killed since March 
One direct consequence of this is that the expression cannot combine with modal morphology, given the (possibly language-specific) rejection of Norwegian prepositions to express mood distinctions.

\section{$2.4 \quad$ Verb movement}

The astute reader has probably noticed that in our analysis, we have to assume a movement operation to obtain the right order. Consider the simplified tree in (44).

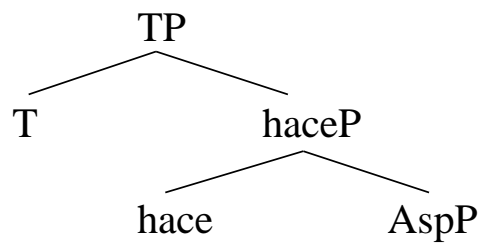

We have reduced our tree to three pieces: the set of heads that correspond to the spell out of hace, the (plausibly also complex) constituent that introduces the time of utterance (TP) and the complex constituent that introduces the focus time. In this base order, we do not get the right linearisation: the hace construction intervenes between the temporal and the aspectual morphology of the verb, but we know that the verb ends up forming a single sequence:

(45) habíamos llegado

had.1pl arrived

Our proposal is the following: the constituent denoting the focus time (e.g., AorP-AspP$v \mathrm{P})$ displaces to a position above hace. This proposal has two parts, one that has to do with the motivation of movement and another one that has to do with the definition of the label of the constituent created after movement.

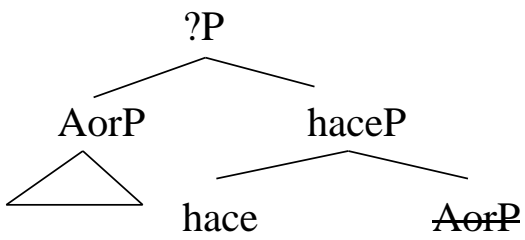

This movement, we argue, is produced in order to agree in aspectual value with hace, whose meaning, as we have seen, is relational in nature; aspect is also relational, so the two sides have to be connected in a complex semantic and syntactic configuration.

From this position (46), we are merging two phrases together. At this point, the label cannot be defined through a simple projection from the head, as we have merged two phrases together (cf. Chomsky 2013). The agreement on aspect value between the two phrases is viewed as feature sharing, and the shared features are those that project their label here. Following the set-based hypothesis of merge (cf. e.g. Gärtner 2002; Citko 2005), each one of the phrases defines a set involving its constituents and their label: respectively, $\{$ Aor $\{$ Aor $\}$ \} and $\{$ hace $\{$ hace, Aor $\}$. Given that the agreement involves the aspectual value, this merge produces the set $\{$ Aor $\{\{$ Aor $\{$ Aor $\}\}\},\{\{$ hace, \{hace, Aor $\}\}\}$, where - in a tree diagram - AorP projects its label, resulting in (47). At 
this point, by definition, only the highest label is defined as a phrase (following Bare Phrase Structure, Chomsky 1995).

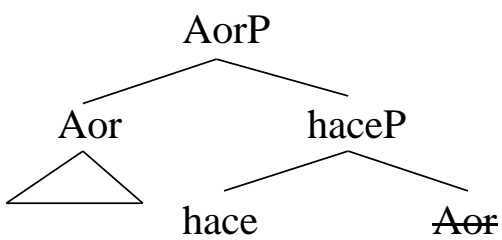

At the following step of the derivation, the tense domain is introduced.

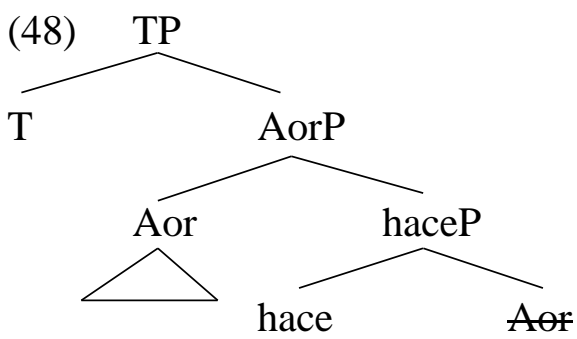

Now, tense and aspect morphology are linearly adjacent, and AorP projects its label inside the T domain; T forms a series of adjacent heads with the constituents of AorP, as (49) shows; this allows synthetic verb-aspect-tense morphology to emerge, through spanning, mirror theory or traditional head movement. We illustrate the situation with the highly irregular form fui 'I.went.aorist':

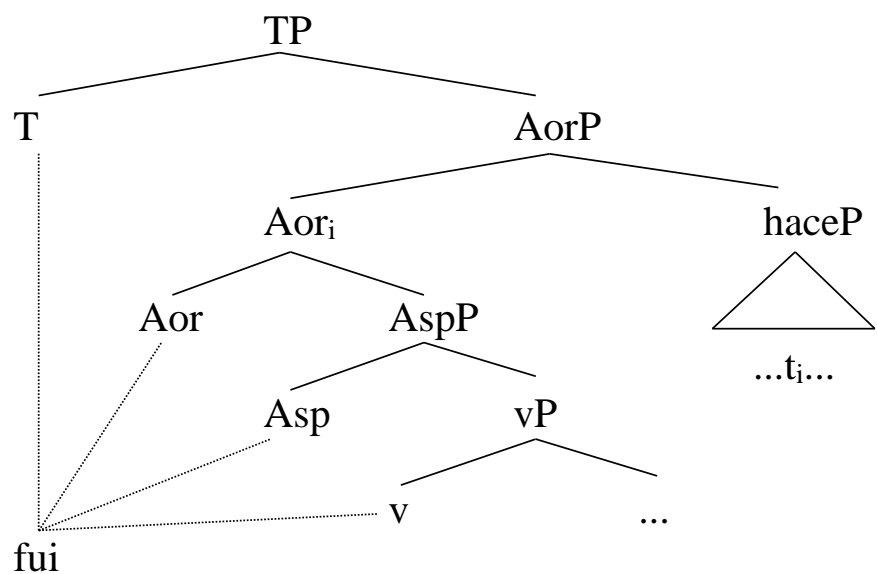

We suggest that the trigger of movement is precisely the morphologically motivated need to have all temporo-aspectual inflection materialised in one single domain, without intervening projections.

We need to say something about English, a language where it has been traditionally assumed that the verb does not rise. In our analysis the situation should be essentially as in Spanish: the form ago has to head a projection that is, in its base position, intermediate between aspect and tense, but it does not emerge between these two domains:

(49) *John did three weeks ago come. 
However, note that different analyses have questioned the traditional English analysis (Julien 2002; Bentzen 2007; see also Harwood 2014), and specifically the assumption that in English the verb does not rise from its base position to a position in the clausal Middlefield. The claim is that English verbs do not displace as much, or as high, as Spanish verbs, but they would indeed displace. This can also be codified in our proposal, if the position where the Spanish AorP moves is higher than a number of adverbial positions, while the same adverbial positions would be projected in English above the position where AorP lands.

\subsection{Summary}

In this section we have argued for the following ideas:

a) Hace-constructions are verbal relators that take the focus time as their internal argument and relate it to the utterance time.

b) They have an internal complex structure, and the nominal expression that accompanies them is the specifier of a degree phrase.

c) In order to form one single series of heads with the tense domain, the syntactic constituent that defines the focus time displaces and reprojects above the hace construction.

With this, we already have the answer to one of our questions: why is it impossible to say, in all varieties of Spanish except for Argentinian Spanish, hace todo el día? Our answer is in (50):

(50) The nominal expression that accompanies hace is a measure phrase; measure phrases are restricted to indefinite QPs.

\section{The structure of hace dos días que}

As Brucart (2014) notes, there are two families of analyses of hace dos días que ("it has been two days since") in Spanish.

(51) Hace dos días que llegó.

make two days that arrived.3sg

"It has been two days since he arrived."

The first family, where our proposal is included, proposes that this construction is derivationally related to the construction hace dos días ("two days ago"); the second proposal, where Brucart’s (2014) own analysis and García Fernández (2000) are included, argues that each construction is generated independently of each other, albeit using the same core predicate, that has slightly different argument selectional properties.

The first family of analyses has two versions. The first version, attending to diachronic evidence that shows that hace dos días que appears docuemented before hace dos días, argues that hace dos días is derived from hace dos días que (Franco 2012). The second analysis derives hace dos días que from hace dos días (Rigau 2001). Here we will essentially adhere to Rigau's (2001) analysis, which in a sketchy form can be characterised as follows: the proposal is that hace dos días (a VP-adjunct, in this proposal) displaces to a position inside the CP layer of the clause, which Rigau (2001) identifies 
with a ModifierP (see Rizzi 1999, 2004 for the properties of that projection). The que ("that") that accompanies the construction is the spell out of finiteness, and carries aspectual information.

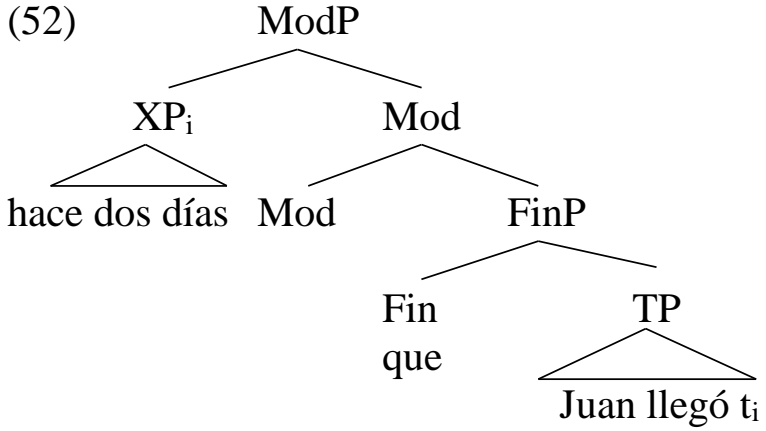

It is necessary, thus, to provide evidence in favour of a movement analysis. What follows is intended as a set of contrasts that show that the two constructions can be related derivationally, and in fact, through A'-movement.

First, note that the hace dos días-constituent can establish long-distance relations. The example in (53) admits two readings: it can be associated to the first verb ("He has been telling me for two days..."), but also to the second ("He tells me that it has been two days since he arrived"). The first reading is expected for both analysis, with and without movement, but the second reading forces a movement analysis, because hace ("make") would never take que llegó ("that he arrived") as an argument.

(53) Hace dos días que Juan me dice que llegó.

make two days that Juan me tells that arrived.3sg

"Juan tells me that it has been two days since he arrived." or "Juan has been telling me for two days that he arrived."

A movement analysis simply has to say that when the temporal expression is associated to the most embedded clause, it was generated there and underwent long movement.

Secondly, this long-distance dependency is sensitive to (weak) islands. The examples in (54a) and (54b) are two cases of interrogative islands, and (54c) is a conditional island. As expected, the only possible reading is the one where the temporal expression modifies the first clause.

(54) a. \#Hace dos días que me pregunta quién llegó. make two days that me asks who arrived "He has been asking me for two days who arrived." not "He asks me who arrived two days ago."

b. \#Hace dos días que no sabe si él llegó.

make two days that not knows whether he arrived

"He has not know whether he arrived for two days." not "He does not know whether he arrived two days ago."

c. *Hace dos días que Luis está contento si María llegó.

make two days that Luis is happy if María arrived

Intended: "Luis is happy if María arrived two days ago." 
Another advantage of Rigau's analysis is that we are not forced to consider that hace dos días que involves some form of subordination. García Fernández (2000) argued that the sequence [que + finite verb] corresponds to a subject clause in cases like (55) and to an adverbial clause in cases like (56). However, the first clause cannot be substituted by eso ("that") (55b), something that would be a unique case in the domain of subject clauses; it is also unclear why the second clause cannot be substituted by temporal adverbs like entonces ("then”).

(55) a. Hace dos días que espero. make two days that wait.I "I have waited for two days."

b. *Hace dos días eso. make two days that

(56) a. Hace dos días que lo vi. make two days that him saw "I saw him two days ago."

b. *Hace dos días entonces. make two days then

For completeness, note that the [que + finite verb] cannot be analysed as a relative clause either, because que cannot be substituted by relative pronouns.

(57) *Hace dos días los cuales llegó. make two days the which arrived.3sg

Our account can also account for a property that is not clearly captured in a nonderivational analysis. García Fernández (2000: 161) notes that hace dos días que has propositional content (58a), while hace dos días does not (58b). This can be shown by the fact that the first can be subordinated to a verb of speech, but the second would constitute an incomplete proposition.

(58) a. Juan dice que hace mucho tiempo que te conoce. Juan says that make lot.of time that you knows "Juan says that it has been a long time since he knows you."

b. *Juan dice que hace mucho tiempo. Juan says that make lot.of time *“Juan says that long time ago."

In Rigau's (2001) analysis, this is also captured, because hace mucho tiempo que is contained in a CP-layer constituent, and thus the position it occupies forces that the constituent is a proposition, while in its base position the constituent is a fragment of the Middlefield.

Finally, the different position of the same constituent in each construction explains another property noted in García Fernández (2000): hace dos días que appears in subjunctive if subordinated to a verb that induces this mood (59a), but hace dos días does not (59b). 
(59) a. No creo que haga dos días que no la veo. not believe that make.subj two days that not her see.1sg "I don't think that it has been two days since I last saw her."

b. *No creo que la viera haga dos días. not believe that her saw.subj make two days Intended: "I don't believe that I saw her two days ago."

We already saw that hace ("make”) must contain uninterpretable features that force agreement with tense and aspect under certain conditions. Assuming that these uninterpretable features can extend to mood under some cases, the contrast in (59) is explained as follows: in (59a) the expression is in the CP domain, and it is locally controlled by a modal inductor in the verb that selects the proposition; however, in (59b), the temporal expression is considerably lower, and the main verb intervenes between the modal inductor and it. If subjunctive in this kind of subordinate clause is marked in the $\mathrm{C}$ domain - the layer that the modal inductor selects - then the rule is that the verbal form that is closer to that domain is the one that manifests the features.

Brucart (2014) notes a potential problem with Rigau's (2001) analysis: the existence of constructions like (60), which García Fernández (2000) and Brucart (2014) take as varieties of the hace dos días que-construction:

(60) Hace dos días de su boda.

make two days of her wedding

"It has been two days since her wedding."

Brucart (2014) notes two problems for the movement analysis, under the light of this construction: first, here we do not have a clausal constituent to base-generate hace dos días; second, que is here replaced with de ("of"). Brucart (2014) notes that de typically marks dependency, something expected if the construction is analysed as a main verb that takes two arguments, but unexpected if que is an aspectual operator.

We agree partially with Brucart (2014): the example in (60) has to be analysed without movement, and presumably it is a case of hacer as an impersonal main verb that takes the $\mathrm{PP}$ as one of its arguments. Where we disagree is in the proposal that (60) is a version of the hace dos días que structure. We contend that (60) and hace dos días que are unrelated, and that while a movement analysis is impossible in (60), the evidence shown before argues in favour of a movement analysis for hace dos días que. Our main piece of evidence is that (60) allows for a set of temporal forms that hace dos días que does not allow.

Hace dos días que (excluding the subjunctive form, which we have already analysed) allows exactly the same forms as hace dos días: imperfective past and, for some speakers, future:

(61) a. Hacía dos días que la había visto. made.impf two days that her had seen "He had seen it two days before."

b. Cuando lleguen sus padres, hará dos días que habrá terminado la tesis. when arrive.3pl his parents, will.make two days that will.have finished the dissertation 
All the other forms are, at best, marked:
a. *(El lunes) hizo dos días que la vi. the Monday made.aor two days that her saw
b. *(Hoy) ha hecho dos días que la vi. today has made two days that her saw

Such restrictions do not apply for (60), showing that here, indeed, we have a full verbal form, as Brucart's (2014) analysis predicts. For speakers that do not accept (61b), (63a) is much better. The same temporal freedom is possible with a subordinate clause when it is introduced by a preposition (cf. 63d vs. 62a):

(63) a. El lunes hará dos semanas de tu boda. the Monday will.make two weeks of your wedding "On Monday, it will be two weeks since your wedding"

b. El lunes hizo dos semanas de tu boda. On Monday made.aor two weeks of your wedding "On Monday, it was two weeks since your wedding."

c. Hoy ha hecho dos semanas de tu boda. today has made two weeks of your wedding "Today it has been two weeks since your wedding."

d. (El lunes) hizo dos días desde que la vi. the Monday made.aor two days since that her saw "On Monday, it was two days since I saw her."3

Thus, our claim is that there are three 'structures', with the first and the second related derivationally, but the third being genetically unrelated to both.

(64) a. hace dos días: temporal relator in the Middlefield

b. hace dos días que: temporal relator displaced to the CP domain

c. hace dos días $P$ : main verb with temporal arguments

Now, if this is right, we have the answer to our second question: why cannot we say Hace todo el día que... ("it has been the whole day that")?

\footnotetext{
${ }^{3}$ Some speakers accept sentences like (62a), but it can be shown that they are actually using a ø preposition to introduce the subordinate clause, which means that the structure is subjacently the one for hacer as a main verb, not the result of movement as in our analysis:
}

(i) (El lunes) hizo dos días ø que la vi. the monday made.aor two days ø that her saw

This can be shown because the silent $\mathrm{P}$ needs to be in the complement position of the verb in order to be licensed; speakers that accept (i) reject (ii):

(ii) *Que la vi, el lunes hizo dos días that her saw, the Monday made.aor two days

This does not happen when the $\mathrm{P}$ is overt:

(iii) Desde que la vi, el lunes hizo dos días. since that her saw, the Monday made.aor two days 
(65) Hace dos días que is derived from hace dos días; like in hace dos días, here the nominal expression is a measure phrase, and measure phrases must be indefinite QPs.

\subsection{On some differences}

However, there is one interpretative difference between the two structures: compare the pair in (66).

(66) a. *Juan espera hace una hora. Juan waits make one hour

b. Hace una hora que Juan espera. make one hour that Juan waits "John has waited for one hour."

The hace dos días que-construction can denote paths. While hace dos días is forced to denote a single temporal point, hace dos días que can denote a path, taken as a sequence of points (an interval) that starts at the starting point of the event and stretches until the utterance time. Thus, (66b) means that Juan's waiting started one hour ago and continues now. This is reflected in the well-known difference represented in (67) and (68): while hace una hora can be an answer to (67b) but not (67c), hace una hora que can be an answer to (68b) but not (68c).

(67) a. Llegó hace una hora. arrived.3sg make one hour "He arrived one hour ago."

b. ¿Cuándo llegó? when arrived.3sg? "When did he arrive?"

c. *¿Cuánto tiempo llegó? how.much time arrived.3sg? “(For) how long did he arrive?”

(68) a. Hace una hora que espera. make one hour that waits

b. ¿Cuánto tiempo espera? how.much time waits?

"How long has he waited?"

c. *¿Cuándo espera? when waits?

"When is he waiting?"

This can have two different explanations, potentially. The first one is that hace dos días contains a PathP in such cases, as represented in (69).

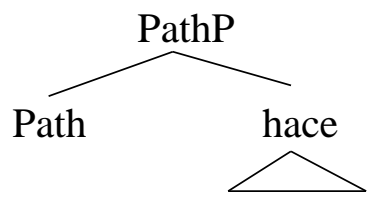


This path phrase is the one that allows the temporal expression to pick a time interval and not a point. However, this solution is unlikely. We would be forced to say that whenever the (silent) PathP is projected in the structure, hace dos días has to displace to the CP domain. However, displacement is not compulsory whenever hace dos días contains only the place structure. It is implausible that presence of a PathP in the structure would force displacement to the CP domain: the reasons is that we find cases of hace + Path that do not involve movement:

(70) Espera desde hace dos días. waits since make two days "He has waited since two days ago."

By brute force, we could simply stipulate that the silent PathP contains a feature that has to be matched with Mod, forcing movement to ModP. This solution, while difficult to argue against, is clearly ad hoc.

The second solution, which we will try to sketch here, is to capitalise on Rigau's (2001) proposal that the que that appears in our construction is a temporo-aspectual operator. As such, we can expect it to modify the situation contained below it in such a way that the hace expression can take a different temporal point to build its vector.

Consider the sentences in (71).

(71) a. *Juan odia a su madre hace dos meses.

Juan hates ACC his mother make two months

b. Juan odiaba a su madre hace dos meses.

Juan hated.impf ACC his mother make two months

c. Juan escribió su novela hace dos meses. Juan wrote.aor his novel make two months

d. Juan escribía su novela hace dos meses. Juan wrote.impf his novel make two months

We argued in section 2.3 that the problem with (71a) is that there is no salient point inside the situation described that can be taken as the origin of the vector. In (71b), in past tense, we can assume that there was an endpoint of the relevant time interval, preceding the utterance time, and we can take that point as the origin of our vector. In (71c), the situation is simpler, because the origin of the vector is the event's culmination, highlighted by the aorist viewpoint; in (71d) we know that the origin of the vector has to be a point preceding the event's culmination, and contained in an interval that precedes the utterance time. Consider now (72):

(72) Hace dos meses que Juan odia a su madre. make two months that Juan hates ACC his mother "It has been two months since Juan started hating his mother."

As the gloss tries to make clear, here the problem posed by (71a) has been solved because the vector originates in the starting point of the state. We know that Individual Level states do not need to have a starting point in the relevant temporal interval (e.g. Water is a liquid), but in our construction we force the interpretation that there is a relevant starting point, that is, that Juan has not always hated his mother. What the vector does in these 
cases is to take the starting point as its origin, and extend; the result, necessarily, is that we deduce that the situation described has extended over some time and includes the utterance time. Thus, we do not need to propose a path preposition for such cases, because taking the starting point of the event (instead of its endpoint or a point preceding the culmination) produces the same interpretative result.

What we need, then, is to say that the temporo-aspectual operator identified by Rigau (2001) anchors the vector to the starting point of the event (here represented as [):

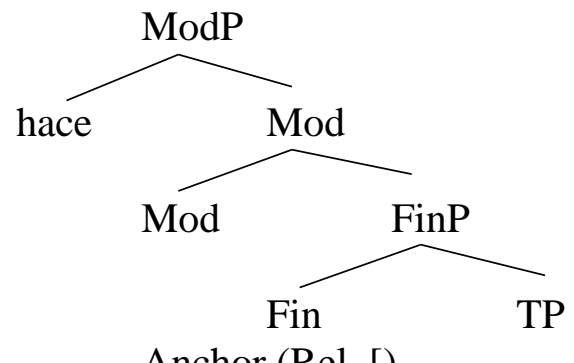

This anchoring function matches the expected role of finiteness in several accounts (Giorgi 2009; Wiltschko 2014): while the aspectual area defines a certain viewpoint, tense and its associate projections (with finiteness probably being in the transition between $\mathrm{T}$ and $\mathrm{C}$ ) have as a role to anchor the members of the situation to particular entities in a given dimension - in the case of Indo-European languages, generally, a temporal dimension. The proposal is obviously indebted to Rigau (2001), with the difference that we do not need to associate an aspectual function to finiteness: its role is anchoring, as in other cases.

\section{The Italian way}

We have not yet answered our third question: why can a variety of Argentinian Spanish say something like (74)?

(74) Hace todo el día que espero.

make all the day that wait.1sg

"I have waited for the whole day."

Given our previous analyses, it is clear that (74) cannot be generated through movement of a prepositional structure containing a measure phrase. There has to be another source for the hace dos días que-construction in this variety.

At this point, it is worth noticing that in Italian it is actually possible to have a nominal equivalent of todo el día ("all the day") in a temporal construction similar to ours.

(75) È tutto il giorno che aspetto.

is all the day that wait.1sg

"I have waited for the whole day."

However, this kind of modifier is impossible with the hace dos días kind of temporal expression; note also that Italian uses two separate verbs for each one of the constructions: essere ("be") for the equivalent of hace dos días que and fare ("make"). All these facts 
decidedly argue against a derivational analysis of the form that we have proposed in Spanish, and in favour of treating both constructions as being genetically unrelated.

(76) a. È arrivato due ore fa. is arrived two hours make "He arrived two hours ago."

b. *È arrivato tutto il giorno fa. is arrived all the day make Intended: "He arrived one whole day before."

These facts also suggest that the analysis of fa constructions in Italian has to be along the lines of our hace dos días type of expression.

Our contention is the following: in almost all varieties of Spanish, hace dos días and hace dos días que are derivationally related; in Italian, however, they are not and distinct structures are used for each case. Argentinian Spanish, or at least the variety we have presented in section 1, despite its superficial similarity to the other Spanish varieties, constructs the hace dos días que in an Italian way. In this construction, the nominal expression is not a measure phrase, and this allows todo el día ("all the day") kinds of expressions.

Benincà (1978) analyses è due ore che structures in Italian and argues, in fact, against a movement analysis (1978: 238). Adapting her labels to a more modern terminology, here is the core of what she argues for:

a) The verb essere ("be") is combining with two constituents: a situation, corresponding to a constituent lower than CP (S") and a temporal modifier.

b) In this sense, essere is acting as a 'strong' verb with its own semantics and selectional restrictions. In fact, it imposes the constraint that the temporal modifier must denote a duration, and does not locate in time (Benincà 1978: 238):

(77) a. È tutto il giorno che ti aspetto.

is all the day that you wait.1sg

"I have waited for you for the whole day."

b. *E le tre che ti aspetto.

is the three that you wait.1sg

Intended: "I have waited for you since 3."

c. *È ieri che sono a Padova.

is yesterday that am in Padova

Intended: "I have been in Padova since yesterday."

Adapting Benincà's (1978) analysis to a more updated terminology, arguably, takes us to Brucart's (2014: 10) analysis of hace dos horas que kind of constructions, which, we argue, is accurate for the variety of Argentinian Spanish discussed here, for Italian and presumably for English, but not for the Spanish varieties that do not accept todo el día as a temporal expression. 
(78)

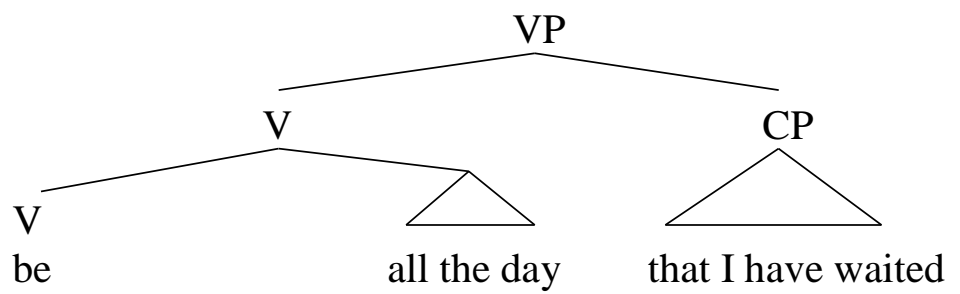

However, we require two adaptations. The first one has to do with the claim that the quecomponent is a subordinate CP. We have seen evidence against it, and it is also dubious that a CP, which denotes a proposition, has the right semantic type for a temporal predicate; we suggest that it is the expansion of a unit smaller than $\mathrm{CP}$ - perhaps, FinP, to the extent that this aspect of Rigau's (2001) analysis is compatible with Brucart’s (2014).

Secondly, another place where we part ways with Brucart's (2014) analysis is the nature of the nominal expression; Brucart (2014) treats it as a measure phrase, but we have already seen that this cannot be right. We propose to follow Benincà (1978) in the claim that the nominal expression is a durative complement of the verb. Mutatis mutandis, the set of nominal expressions that are accepted by temporal-essere in Italian/temporal-hacer in the Argentinean variety correspond to those accepted by durar ("last") in all Spanish varieties (to the best of our knowledge), with the minimal difference of the categorial nature of the second argument:

(79) a. Duró una hora.

lasted one hour

"It lasted one hour."

b. Duró todo el día.

lasted all the day

"It lasted for the whole day."

c. Duró dos horas.

lasted two hours

"It lasted two hours."

d. *Duró ayer.

lasted yesterday

e. *Duró las tres.

lasted the three

Our proposal, then, is the one in (80), where DurP stands for Durative Phrase, Arg stands for 'in the Argentinean variety' and essere ${ }^{\text {Temp }}$ stands for 'temporal-essere':

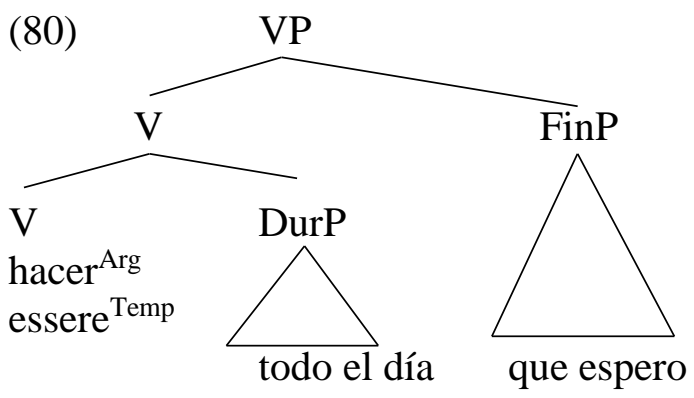

We have, thus, an answer for our third question: why does the Argentinean variety allow todo el día as a nominal expression with hace dos días que? 
(81) In this variety, like in Italian, hace dos días que is not generated through movement of a temporal relator, but corresponds to a main temporal verb that takes a durative argument. Todo el día can function as a durative argument.

\section{Conclusions}

In this article we have argued for the following ideas:

a) Hace dos días ("two days ago") structures correspond to the spell out of a temporal relator; the nominal expression that accompanies it is a measure phrase giving the length of a vector projected from the focus time.

b) In Spanish, hace dos días que allows two analyses. In most varieties, it is the result of the movement of the temporal relator to the CP area. These varieties reject todo el día as a nominal expression also in this construction.

c) In the Argentinean variety, hace dos días que - despite its superficial similarities to (b) - corresponds to the projection of a temporal verb that takes two arguments: a durative phrase and a FinP.

It is almost a common place that the Argentinean variety is influenced by Italian, and in this sense our analysis might be interpreted as the effect of a deep influence of Italian in this variety. However, we would like to distance ourselves from that possible conclusion. The two ways of analysing a sequence like hace dos días que seem to express two possible alternatives that are, in principle, equally possible, and it is unclear which further properties of the varieties under consideration lead the speakers to one interpretation or the other.

\section{References}

Benincà, P. 1978. Sono tre ore che ti aspetto. Rivista di Grammatica Generativa 3(2): 231-245.

Bentzen, K. 2007. Order and structure in embedded clauses in Northern Norwegian. PhD dissertation, University of Tromsø. Available online: http://munin.uit.no/handle/10037/1209 (Accessed 6 January 2015).

Bertinetto, P.M. and D. Delfitto. 2000. Aspect vs. actionality: some reasons for keeping them apart. In Ö. Dahl (Ed.) Tense and aspect in the languages of Europe. Berlin: De Gruyter. pp. 189-225.

Bobaljik, J.D. 1994. What does adjacency do? MIT Working Papers in Linguistics 22: 132.

Bosque, I. and Á. Gallego. 2011. Spanish double passives and related structures. Revista de Estudos Linguisticos da Universidade do Porto 6: 9-50.

Bravo, A. 2008. La perífrasis “ir a + infinitivo" en el sistema temporal y aspectual del español. PhD dissertation, Universidad Complutense de Madrid. Available online: http://eprints.ucm.es/8074/ (Accessed 8 August 2015). 
Brody, M. 2000. Mirror theory: syntactic representation in perfect syntax. Linguistic Inquiry 31: 29-56.

Brucart, J.M. 2014. Un análisis derivacional de las construcciones temporales con hacer. Ms., Universitat Autònoma de Barcelona.

Brugè, L. and A. Suñer. 2009. Building up complex temporal constructions. Venice Working Papers in Linguistics 18: 7-63.

Caha, P. 2009. The nanosyntax of case. PhD dissertation, University of Tromsø. Available online: http://munin.uit.no/bitstream/handle/10037/2203/thesis.pdf?sequence=1 (Accessed 10 August 2014).

Carlson, G.N. 1977. Reference to kinds in English. PhD dissertation, University of Massachussets. Available online: http://scholarworks.umass.edu/dissertations/AAI7726414/ (Accesed 15 August 2014).

Chomsky, N. 1957. Syntactic structures. The Hague: Mouton.

Chomsky, N. 1995. Bare phrase structure. In H. Campos and P. Kempchinsky (Eds.) Evolution and revolution in Linguistic Theory. Washington: Georgetown University Press: 51-109.

Chomsky, N. 2013. Problems of projection. Lingua 130: 33-49.

Chomsky, N. and M. Halle. 1968. The Sound Pattern of English. New York: Harper \& Row.

Citko, B. 2005. On the Nature of Merge: External Merge, Internal Merge, and Parallel Merge. Linguistic Inquiry 36: 475-497.

Franco, L. 2012. Movement triggers and the etiology of grammaticalization: the case of Italian preposition fa. Sintagma 24: 65-83.

García Fernández, L. 2000. La gramática de los complementos temporales. Madrid: Visor.

Gärtner, H.M. 2002. Generalized transformations and beyond. Berlin: Akademie Verlag.

Giorgi, A. 2009. About the speaker: towards a syntax of indexicality. Oxford: Oxford University Press.

Goldsmith, J.A. 1976. Autosegmental phonology. PhD dissertation, MIT. Available online: http://www.ai.mit.edu/projects/dm/theses/goldsmith76.pdf (Accessed 6 March 2015).

Halle, M. and A. Marantz. 1993. Distributed morphology and the pieces of inflection. In K. Hale and S. J. Keyser (Eds.) The view from Building 20. Essays in Honor of Sylvain Bromberger. Cambridge (Mass.): MIT Press. pp. 111-176.

Harwood, W. 2014. Rise of the auxiliaries: a case for auxiliary raising vs. affix lowering. The Linguistic Review 31(2): 295-363. 
Julien, M. 2002. Syntactic heads and word formation. Oxford: Oxford University Press.

Klein, W. 1994. Time in language. London: Routledge.

Marantz, A. 1988. Clitics, morphological merger and the mapping to phonological structure. In M. Hammond and M. Noonan (Eds.) Theoretical morphology. New York: Academic Press. pp. 253-270.

Milsark, G. 1974. Existential sentences in English. PhD dissertation, MIT. Available online: https://dspace.mit.edu/handle/1721.1/13021 (Accessed 1 September 2014).

McNally, L. 1994. Adjunct predicates and the Individual/Stage Distinction. Proceedings of the 12th WCCFL. pp. 561-576.

Piñón, C. 1997. Achievements in an event semantics. A. Lawson and E. Cho (Eds.) Proceedings of SALT 7. Ithaca (NY): CLC Publications. pp. 273-296.

Preminger, O. 2014. Agreement and its failures. Cambridge (Mass.): MIT Press.

Ramchand, G. and P. Svenonius. 2013. Deriving the functional hierarchy. Ms., University of Tromsø. Available online: ling.auf.net/lingbuzz/002028/current.pdf (Accessed 5 July 2014).

Ramchand, G. 2008. Verb meaning and the lexicon. Cambridge: Cambridge University Press.

Rigau, G. 2001. Temporal existential constructions in Romance. In I. d’Hulst, J. Rooryck and J. Schroten (Eds.) Romance languages and linguistic theory 1999. Amsterdam: John Benjamins. pp. 307-333.

Rizzi, L. 1999. On the position of Int(errogative) in the left periphery of the clause. Ms, University of Siena. Available online: www.ciscl.unisi.it/doc/doc_pub/int.doc (Accessed 1 February 2015).

Rizzi, L. 2004. Locality and left periphery. In A. Belletti (Ed.) Structures and beyond. The cartography of syntactic structures, vol. 3. Oxford: Oxford University Press. pp. 104-131.

Romeu, J. 2013. Cartografía mínima de las construcciones espaciales. PhD dissertation, Universidad Complutense, Madrid. Available online: http://eprints.sim.ucm.es/25969/1/T35421.pdf (Accessed 10 October 2014).

Sáez del Álamo, L.Á. 1987. Caracterización de “hace-expresión temporal” en el marco de la Rección y Ligamiento. Lenguajes naturales y lenguajes formales 3: 713-722.

Smith, C. 1991. The parameter of aspect. Dordrecht: Kluwer.

Starke, M. 2009. Nanosyntax: a short primer to a new approach to language. Nordlyd 36: $1-6$. 
Svenonius, P. 2008. Projections of P. In A. Ashbury, J. Dotlacil, B. Gehrke and R. Nouwen (Eds.) Syntax and semantics of spatial P. Amsterdam: John Benjamins. pp. 63-84.

Svenonius, P. 2010. Spatial P in English. In G. Cinque and L. Rizzi (Eds.) Mapping spatial PPs. The cartography of syntactic structures 6. Oxford: Oxford University Press. pp. 127-160.

Svenonius, P. 2012. Spanning. Ms., CASTL, University of Tromsø. Available online: ling.auf.net/lingbuzz/001501/current.pdf (Accessed 3 August 2014).

Talmy, L. 1972. Semantic structures in English and Atsugewi. PhD dissertation, University of California, Berkeley. Available online: http://linguistics.buffalo.edu/people/faculty/talmy/talmyweb/Dissertation/Intro.pdf (Accessed 15 February 2015).

Talmy, L. 1983. How language structures space. In H.L. Pick and L.P. Acredolo (Eds.) Spatial orientation. Theory, research and application. New York: Plenum, 225-282.

Wiltschko, M. 2014. The Universal Structure of Categories. Towards a Formal Typology. Cambridge: Cambridge University Press.

Wunderlich, D. 1991. How do prepositional phrases fit into compositional syntax and semantics? Linguistics 29: 591-621.

Zucchi, S. 1993. The language of propositions and events. Dordrecht: Kluwer.

Zwarts, J. 2005. Prepositional aspect and the algebra of paths. Linguistics and Philosophy 28: 739-779.

Zwarts, J. and Y. Winter. 2000. Vector space semantics: a model theoretic analysis of locative prepositions. Journal of logic, language and information 9: 169-211. 